\title{
Tannin Extraction from Bark of Rhizophora Mucronata Using Soxhlet and Boiling Techniques
}

\author{
Ahmad Hafizan Muhammad Muhayyidin", Nurul Aimi Ghazali", Noor Fitrah Abu Bakar \#, Wan Asma Ibrahim*, \\ Arina Sauki ${ }^{\#}$, and Zulkafli Hassan ${ }^{+}$ \\ ${ }^{\#}$ Faculty of Chemical Engineering, Universiti Teknologi MARA, 40450 Shah Alam, Selangor, Malaysia \\ E-mail: hafizan.muhayyidin@gmail.com; nurulaimighazali@gmail.com;drnoorfitrah@gmail.com; arinasauki@gmail.com \\ "Forest Research Institute Malaysia (FRIM), 52109 Kepong, Selangor, Malaysia \\ E-mail:wanasmai@gmail.com \\ ${ }^{+}$Faculty of Chemical and Natural Resources Engineering, Universiti Malaysia Pahang, 26600 Pekan, Pahang, Malaysia \\ E-mail: zulkafli@ump.edu.my
}

\begin{abstract}
Extraction of tannin Rhizophora Mucronata barks by using two methods, which were soxhlet extraction and boiling were demonstrated in this study in order to evaluate the effective technique for extraction. Several parameters such as the type of solvent used, time of extraction, and sample size were specified. The extractant was then evaporated using vacuum rotary evaporator. The percentage of extractives and the characterization of condensed (Stiasny Index) and hydrolyzable tannins were all quantified. The milled barks with different sizes were introduced to the extraction using water, methanol, acetone, and toluene as a solvent for three, six and nine hours for Soxhlet extraction while for boiling only water were used as a solvent and at four, six and eight hours. Results demonstrated that extraction from the bark of Rhizophora Mucronata with water for six and nine hours extracted approximately 29 wt $\%$ and $13 w t \%$ for both soxhlet extraction and boiling respectively when coupled with vacuum rotary evaporator. The Soxhlet extraction method was superior as compared to boiling. The optimum parameters for the Soxhlet extraction were water as the solvent at six hours extraction with $0.5 \mathrm{~mm}$ of milled bark particles size that extracted $29 \mathrm{wt} \%$ of extractives. The condensed tannin and hydrolyzable tannin of the extractives using soxhlet extraction were approximately $76 \mathrm{wt} \%$ and $0.00133 \mathrm{wt} \%$ respectively.
\end{abstract}

Keywords — tannin; soxhlet extraction; Rhizophora Mucronata; tannin characterization.

\section{INTRODUCTION}

Bioactive compounds are undergoing an increasing awareness in a wide range of application: food industry, geomedicine, nano-bio-science, oil, and gas industry [1]. Bioactive compounds such as phenolic compounds, vitamins, minerals [2] were isolated and identified from vegetables, fruits, nuts, flowers, leaves [3] by right it can be concluded that bioactive compounds exist naturally abundant in the plant. The "bioactive" term is comprised of two words: biowhich refers to life in Greek and -active that means full of energy or involve activities. In a firmly scientific point, it is an alternate term for biologically active and hence making bioactive compound which simply a substance with biological activity. For every single system, it has its main function such as protecting agents against radiation in plant and oxidation inhibitor to prolong shell life of foods in the food industry [4]. Phenolic is diverse group compounds that include phenolic acids, flavonoids and also tannins are important to bioactive compounds [5]. All those group compounds are reliable for their cardiovascular protective, antioxidant, anti-inflammatory, antitumor and antibacterial [6].

Tannins, which can leather from animal skins, consist of a set of elements taking place in several upper plant types. The development is succeeded correlating the peptide bonds of amino acids present in animal protein with the hydroxyl groups of tannins, known as collagen, [7]. Also, the tanning action, it also used in floors and tiles industries, and the drilling process in oil and gas exploration [8], [9].

Condensed and hydrolyzable tannin are the two common groups existed in tannin [10]. Condensed tannins comprise of flavonoid units, known as flavan3,4-diols (leucoanthocyanidins) and flavan-3-cells (catechins) [11]. These presented as polymers with several degrees of condensation stretching from 4 to 12 flavonoid units, and according to Stiasny reaction it precipitated in the presence 
of hydrochloric acid and formaldehyde, which hydrolysis would not take place [12]. Hydrolyzable tannins deliberated as polyesters derived from glucose and grouped into two: a) gallotannins, which after hydrolysis produced gallic acid and its derivatives; and b) ellagitannins, released ellagic acid upon hydrolysis [13].

Tannins are formed from tannosome which is a chloroplast-derived organelle and substantially can be discovered in the surface wax or vacuoles of plants, and usually comprises of oil, gum, resin, latex or pigments [14]. The earliest industry in operation using tannin is the leather operation [15]. Animal skin is the by-product from meat industry which became the raw material for the leather industry were collected from slaughterhouses and transformed into stable material [16], [17] called leather which later be used for manufacturing a wide range of products such as clothing, footwear, leather goods, furniture, and other daily used items [18], [19]. The production of leather involves the process which the collagen chains in the skin are cross-linked with the tannins in the tan liquors (solution containing tannins) [20].

Rhizophora Mucronata is the scientific name for Bakau Kurap which is a type of mangrove tree species. In Malaysia, mangrove species cover up to 645,852 hectare (ha), which placed third in Asia in term of the area [21]. This species can be found near swamp or coastal region. It can prevent soil corrosion and also fortification against disasters such as tsunami near coastline area [22]. The trunk can be used to make charcoal while the bark is thrown away as a waste product since it will disrupt the process. In Malaysia, research involving tannins from mangrove is still at the initial and early stage. Among the earlier study were conducted by [23] but worked with Rhizophora Apiculata, which is another species of the mangrove family, that offered a great possibility as a source of tannins for the usage of steel corrosion inhibitors. Thus, this opened chances to study the optimum tannin extraction parameters and the characterization of condensed tannin and hydrolyzable tannin from Rhizophora Mucronata as the source of tannins.

Soxhlet extraction is a well-known method for solidliquid extraction with its advantages. Using a thimble, the sample is placed into it which was then positioned into a condenser extractor where the solvent is in contact from a solvent flask. As the solvent gets to a certain height, it will be overflowed into the solvent flask again. The number of extractives can be increased by simultaneous extraction, and the extractant does not require further filtration since the extraction used a cellulose thimble that prevents direct contact between the solid sample and the solvent [24].

There are several more techniques can be used for solidliquid extraction processes such as high-pressure Soxhlet extraction, ultrasonic-assisted Soxhlet extraction, and microwave-assisted Soxhlet extraction. The application of pressure into the extraction does speed up the extraction process. However, the performance of the extraction process should not be affected under high pressure [25]. As for ultrasonic-assisted Soxhlet extraction, it was designed using the same approach as the conventional Soxhlet extraction with the addition of thermostatic bath at the Soxhlet chamber and ultrasonic probe. Microwave-assisted Soxhlet extraction does maintain the advantages from conventional Soxhlet extraction and also overcomes the disadvantages such as longer time of extraction [26]. Both of the ultrasonic and microwave-assisted Soxhlet extraction have enormously reduced the cycle of extraction but in term of the extraction yield, the conventional Soxhlet extraction produced the highest result compared to both of it for one-stage extraction [27]. It is is the main reason conventional Soxhlet extraction was chosen to be used in this experimental works extraction by boiling also known as decoction that involves heating of the solvent which extracts more compounds from the samples, while soaking or infusion is extraction without applying the heat [28].

Thus, this research demonstrates the extraction methods for tannin from Rhizophora Mucronata using soxhlet and boiling techniques. These two methods of extraction were conducted for evaluating their performance in extracting tannin by varying the milled bark particles sizes, types of solvent used and duration of extractions.

\section{MATERIAL AND METHOD}

\section{A. Bark Origin and Preparation}

The bark of Rhizophora Mucronata as shown in Fig. 1 was collected from a charcoal factory in Kuala Sepetang, Perak. The bark was randomly chosen with average diameter of $14.1 \mathrm{~cm}$, the average length of $165.2 \mathrm{~cm}$ and 30 years of average age. All bark was dried at room temperature for two weeks in order to achieve equilibrium humidity. Then the bark was milled (Fig. 2) before sieving into several sizes which $0.5,1.0$ and $1.5 \mathrm{~mm}$. $5 \mathrm{~g}$ of milled bark was dried at $105 \mathrm{C}$ overnight. The weight loss of the bark was recorded to calculate the total moisture content (MC) of the bark as in Equation (1). Before the extraction experiment, the bark was stored in sealed plastic bags at room temperature.

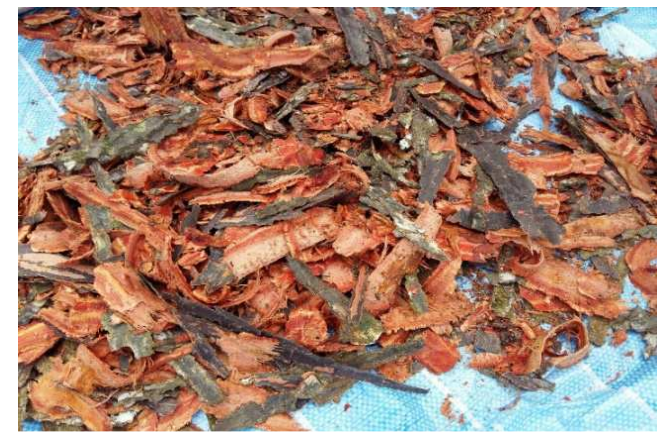

Fig. 1 Rhizophora mucronate barks

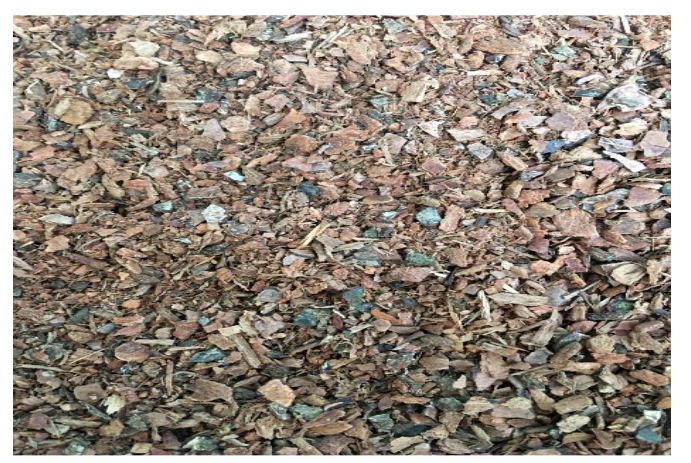

Fig. 2 Milled barks 


$$
M C=\frac{\text { Weight }_{\text {Wet }}-\text { Weight }_{\text {Dry }}}{\text { Weight }_{W e t}} \times 100
$$

\section{B. Tannin Extraction}

1) Soxhlet Extraction: The unsieved milled bark sample was weighted according to dry weight of the bark and was put in the thimble and placed in the extraction chamber as shown in Fig. 3. The material was extracted with bark/solvent ratio of 1:15. $200 \mathrm{~mL}$ of distilled water was poured into a round bottom flask (RBF) as the solvent and heated at boiling temperature for three hours and then it was repeated for six and nine hours. Later, the experiments were repeated using other solvents i.e. acetone, toluene and methanol for six hours extraction time only. All experiments for each sample were repeated for six times. After extraction, the extractant then evaporated using vacuum rotary evaporator. The percentage of extractives was determined based on the dry weight of the milled bark as shown in Equation (2).

$$
\text { Percentage }=\frac{\text { Weight of extractives }}{\text { Weight of milled bark }} \times 100
$$

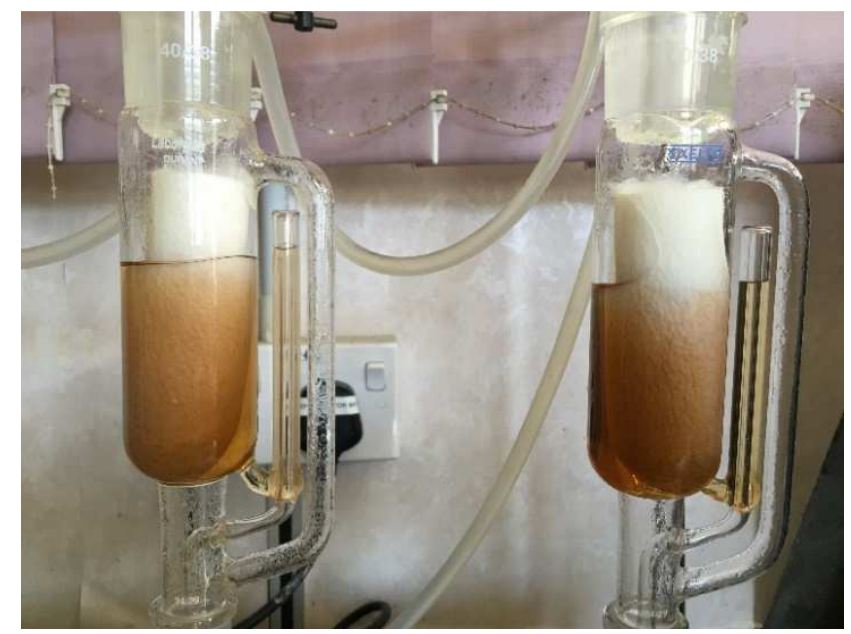

Fig. 3 Extraction chamber with the thimble

Then, the experiments were repeated by using water only as the solvent with different particle sizes of $0.5,1.0$ and 1.5 $\mathrm{mm}$ for 6 hours extraction. For other solvents of extraction, i.e. using methanol, acetone, and toluene with $100 \%$ in volume, the experiments were repeated with the particle size of $0.5 \mathrm{~mm}$ and the time of extraction maintained for 6 hours.

2) Extraction by Boiling: The unsieved milled bark sample was put in a cloth pouch and tied tightly and placed in the solvent, which was distilled water, while heated at 90 ${ }^{\circ} \mathrm{C}$ and stirred for four, six and eight hours as shown in Fig. 4. Using the same bark to the solvent ratio as in the Soxhlet extraction, the volume of the solvent was changed to 1500 and $3000 \mathrm{~mL}$ respectively. Table 2 shows the summary of boiling and soaking methods for the extraction procedures. Distilled water was continuously added to maintain a constant volume of the solvent. After boiling, the cloth pouch was removed, and extractant was evaporated using vacuum rotary evaporator, and the percentages of extractives were calculated using Equation (2). The experiments were repeated by soaking the bark in distilled water at room temperature for 24 hours, and the results were recorded as in Table 2.

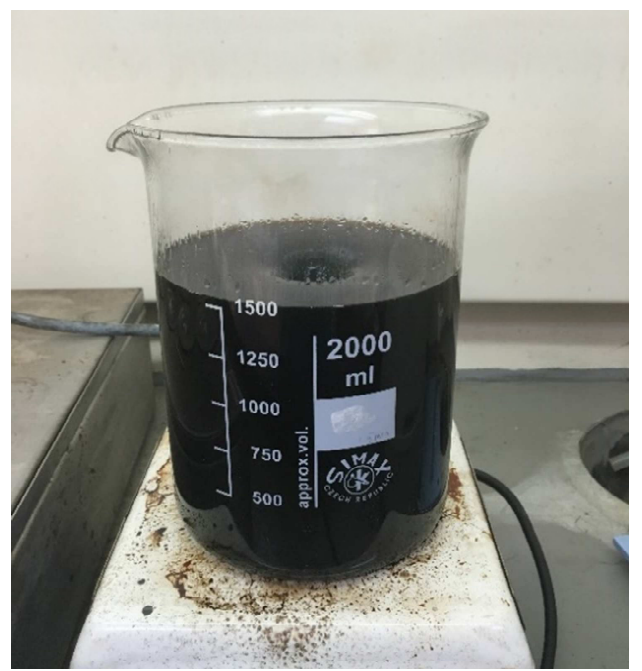

Fig. 4 Extraction by boiling

\section{Tannin Characterization}

The characterization of condensed and hydrolyzable tannin for both extractives from soxhlet extraction and boiling were determined. The percentages of condensed tannin were determined using Stiasny Index method that stated by [29], and Equation (3) was used. Fig. 5 illustrates the reflux process for characterization of condensed tannin. While for the characterization of hydrolyzable tannin the experimental works were done according to a procedure similar to that described by [30].

$$
S I=\frac{\text { mass of tannin obtained }}{\text { mass of total extractive } \mathrm{s}} \times 100
$$

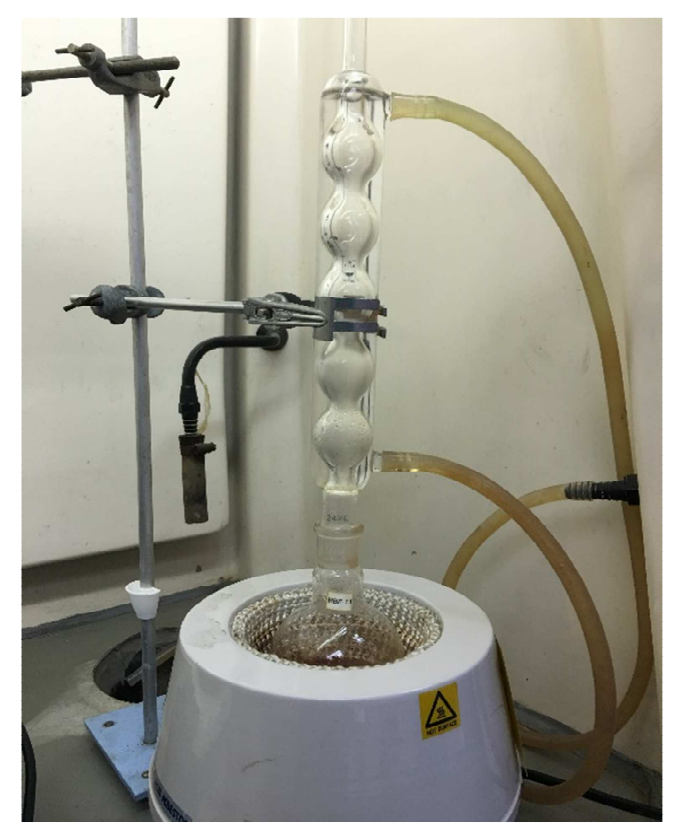

Fig. 5 Reflux setup for condensed tannin characterization 


\section{RESULTS AND DISCUSSION}

\section{A. Soxhlet Extraction}

The average moisture content of the milled bark is 18.81 $\pm 0.1 \mathrm{wt} \%$. The moisture content was analyzed in order to determine the dry weight of the bark used for the extraction process and the value shows that less water will be extracted during the extraction process.

Table 1 shows the increasing in percentage of extractives as the time of extraction increased for three, six and nine hours for water solvent with an unsieved particle size of the milled barks which were $8.22 \pm 0.4 \mathrm{wt} \%, 13.15 \pm 1.6 \mathrm{wt} \%$, and $13.29 \pm 1.5 \mathrm{wt} \%$ respectively. Increasing the time of extraction increased the yield percentage of the extractives as it promoted extensive mass transfer [31]. However, the extractives from six and nine hours were almost similar because there was nothing much left to be extracted from the observation during the experiment. Thus, 6 hours of the extraction time is the preferred condition in this study. For the other solvents, i.e. acetone, toluene and methanol, the average extractives percentage were $3.07 \pm 0.1,0.41 \pm 0.3$ and $11.89 \pm 0.6 \mathrm{wt} \%$ respectively within the same extraction duration of 6 hours. Overall, water acted as a good solvent extraction due to high hydrophilicity of the tannin that causes dissolution of the compounds and dissolved solids. Besides, the color of extractant was darker than the other samples that extracted using organic solvents [32].

TABLE I

EXPERIMENTAL SETS AND PERCENTAGE OF EXTRACTION YIELDED

\begin{tabular}{|c|c|c|c|c|}
\hline $\begin{array}{c}\text { Exp } \\
\text { set }\end{array}$ & Solvent & $\begin{array}{l}\text { Time, } \\
\text { hours }\end{array}$ & $\begin{array}{c}\text { Particle } \\
\text { size, } \mathbf{m m}\end{array}$ & $\begin{array}{c}\text { Extractives } \\
\text { percentage, wt } \% \\
\end{array}$ \\
\hline 1 & \multirow{6}{*}{ Water } & 3 & Unsieved & $8.22 \pm 0.4$ \\
\hline 2 & & 6 & Unsieved & $13.15 \pm 1.6$ \\
\hline 3 & & 9 & Unsieved & $13.29 \pm 1.5$ \\
\hline 4 & & 6 & 0.5 & $28.97 \pm 1.8$ \\
\hline 5 & & 6 & 1.0 & $19.73 \pm 2.5$ \\
\hline 6 & & 6 & 1.5 & $11.75 \pm 2.1$ \\
\hline 7 & \multirow[t]{2}{*}{ Acetone } & 6 & Unsieved & $3.07 \pm 0.1$ \\
\hline 8 & & 6 & 0.5 & $7.35 \pm 1.2$ \\
\hline 9 & \multirow[t]{2}{*}{ Toluene } & 6 & Unsieved & $0.41 \pm 0.3$ \\
\hline 10 & & 6 & 0.5 & $1.86 \pm 0.6$ \\
\hline 11 & \multirow[t]{2}{*}{ Methanol } & 6 & Unsieved & $11.89 \pm 0.6$ \\
\hline 12 & & 6 & 0.5 & $22.70 \pm 0.5$ \\
\hline
\end{tabular}

The unsieved milled bark was also used as the base result for the effect of particle size during the extraction. Referring to Table 1, extraction time of 6 hours for water as a solvent show that the size of the milled bark particles is essential in tannin extraction. The average particle size of milled bark of $0.5 \mathrm{~mm}$ yielded the highest percentage of extractives with $28.97 \pm 1.8 \mathrm{wt} \%$. This amount was followed by $1.0 \mathrm{~mm}$ and $1.5 \mathrm{~mm}$ of $19.73 \pm 2.5 \mathrm{wt} \%$ and $11.75 \pm 2.1 \mathrm{wt} \%$ respectively. The amount of tannin extracted using Rhizophora species obtained by Sulaiman et al. [12] and using the barks of Pinus species by Vieira et al. [33] were 23.85 and $24.84 \%$ respectively. Smaller size particles produced better result compared to larger particles size for greater tannin extraction efficiency [34] as the particle size decreases its contact area with the solvent increases and hence increasing the yield of extraction [35]. Based on the observation during the extraction using large particle size, of
$1.5 \mathrm{~mm}$, the color of the solvent inside the condenser was very light tanned color compared to 0.5 and $1.0 \mathrm{~mm}$ which was dark tanned color - the smallest size of milled bark with 6 hours extraction using toluene produced extractives with average percentage of $1.86 \pm 0.6 \mathrm{wt} \%$. This is followed by acetone, with average percentage of $7.35 \pm 1.2 \mathrm{wt} \%$ and methanol $22.70 \pm 0.5 \mathrm{wt} \%$. Based on these results, acetone and toluene both are not suitable for the extraction of tannin as the yielding is low and not time effective.

\section{B. Extraction by Boiling}

Boiling extraction was conducted as a comparison to soxhlet extraction. In addition, boiling is an easier method as compared to soxhlet and moreover can be done with large amount of sample within short period of time rather than carrying out multiple times of soxhlet extraction. Table 2 shows the average percentage of extractives increased from $10.9 \mathrm{wt} \%$ to $12.9 \mathrm{wt} \%$ with increasing time of extraction from 4 to 6 hours respectively. However, the percentage of extractives decreased to $11.1 \mathrm{wt} \%$ as the time of boiling increased to 8 hours. Prolonged boiling time increases the chance of decomposition and oxidation of phenolics due to their long exposure to unfavorable environmental effects such as temperature, light and oxygen [36]. Moreover, from the point of industrialization point of view, increasing boiling time is not economical. This phenomenon is explained by the Fick's second law of diffusion. The law stated that a final equilibrium between the solute concentration in the solid matrix (bark samples) and in the bulk solution (solvent) might be reached after a certain period of time, then lead to a deceleration in extraction yield [37]. Although the same extraction time of 6 hours was applied in boiling extraction, it was found that during soxhlet extraction, the same solvent was always $100 \%$ concentration in the condenser and it promoted higher extraction rate because of fresh concentration equilibrium. On the other hand, by boiling the water at fixed volume of water, some of it evaporated during the experiment. Hence, the addition of water was needed to keep the volume at constant.

Furthermore, to increase the percentage of the extractive while keeping the amount of sample used constant, control of volume of solvent is an important factor. As the water volume increased, it enhanced the solubility of more extractives in the solvent as long as the extractive was below the saturation point. Larger volume of solvent decreased the concentration but over the time, the amount of extractives yielded increased from $12.9 \mathrm{wt} \%$ to $14.8 \mathrm{wt} \%$ as shown in Table 2. The effect of temperature on the amount of extractive was studied by comparing the yield produced when boiling and soaking the unsieved milled bark sample at the same volume and extraction period. However, after 4 and 8 hours of soaking the sample in water at room temperature, the color of the extractant was too light which indicates that less amount of soluble extractive as shown in Fig. 6 and 7. Hence, the process was extended for 24 hours. The result of soaking for 24 hours was compared with 4 hours of boiling time which were $6.54 \mathrm{wt} \%$ and $10.9 \mathrm{wt} \%$ respectively. This shows that at elevated temperature, the solvent facilitates the solubility of the extractives in the sample during the extraction process by reducing the water viscosity and 
surface tension, thus promoting higher penetration rate of the extractives. Moreover, thermal energy disrupts the strong solute-sample matrix interactions caused by van der Waals forces, hydrogen bonding and dipole attractions between the solute molecules and active sites of the sample matrix [38].

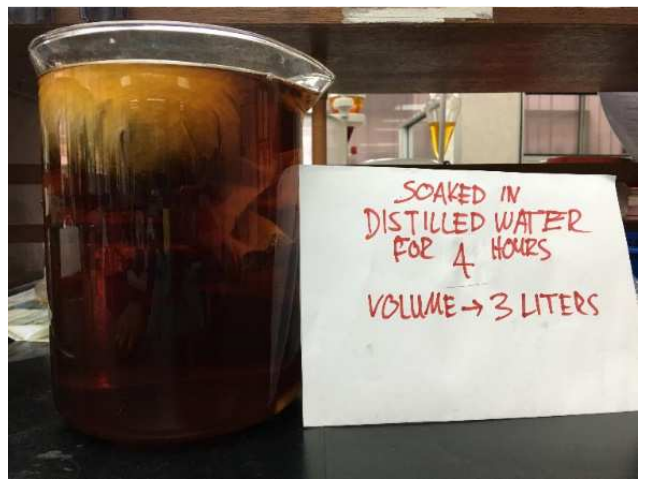

Fig. 6 Sample soaked for 4 hours

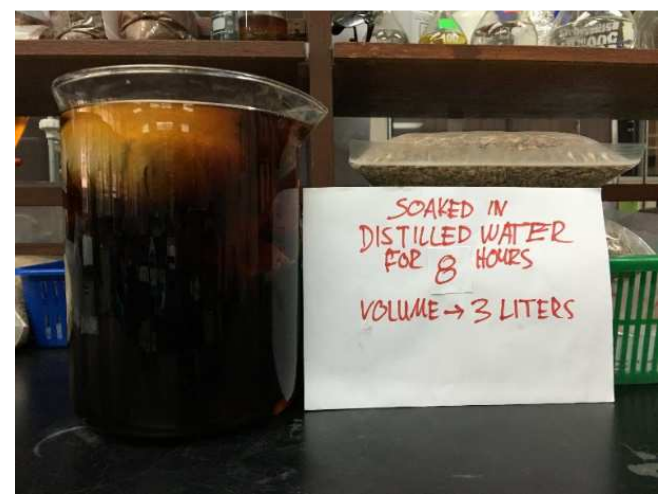

Fig. 7 Sample soaked for 8 hours

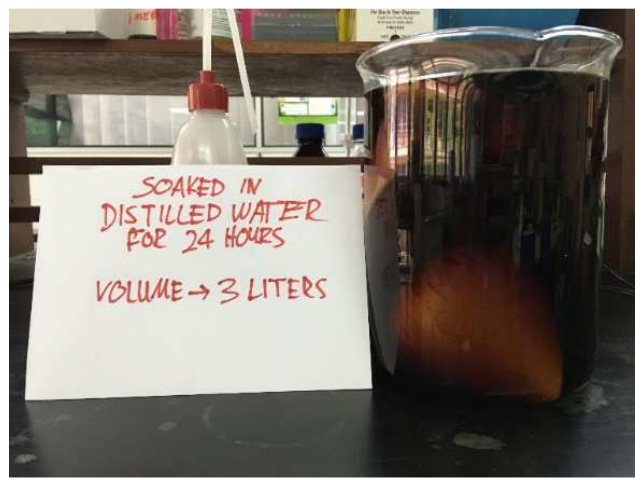

Fig. 8 Sample soaked for 24 hours

TABLE II

EXTRACTION METHODS AND YIELDED EXTRACTIVES.

\begin{tabular}{|l|l|l|l|}
\hline $\begin{array}{c}\text { Extraction } \\
\text { method }\end{array}$ & $\begin{array}{c}\text { The volume of } \\
\text { water, mL }\end{array}$ & $\begin{array}{l}\text { Time, } \\
\text { hours }\end{array}$ & $\begin{array}{l}\text { Extractives } \\
\text { percentage, wt \% }\end{array}$ \\
\hline \multirow{3}{*}{ Boiling } & \multirow{3}{*}{1500} & 4 & 10.90 \\
\cline { 3 - 4 } & & 6 & 12.90 \\
\cline { 2 - 4 } & 3000 & 8 & 11.10 \\
\hline Soaking & 1500 & 6 & 14.80 \\
\hline
\end{tabular}

\section{Tannin Characterization}

Table 3 shows the percentages of condensed tannins, hydrolyzable tannins. The condensed tannins found in the

extraction with water was $75.35 \pm 1.08 \mathrm{wt} \%$ which was superior compared to the result found by [33] but with a different type of sample used, which was pine tree barks. Fig. 9 shows the condensed tannin after characterization process. Furthermore, the percentage of tannins and non-tannins were also slightly higher. While for hydrolyzable tannins obtained from the extractives was $0.00133 \%$. The small percentage indicates that the hydrolyzable tannin decomposed because of the temperature during the extraction. It is found that water temperature above $60{ }^{\circ} \mathrm{C}$ will liberate and released ellagic acid and gallic acid from ellagitannins and gallotannins respectively [39].

TABLE III

CHARACTERIZATION OF TANNINS

\begin{tabular}{|l|l|l|}
\hline \multicolumn{1}{|c|}{ Extraction method } & $\begin{array}{c}\text { Condensed } \\
\text { tannin, wt\% }\end{array}$ & $\begin{array}{c}\text { Hydrolyzable } \\
\text { tannin, wt\% }\end{array}$ \\
\hline Soxhlet extraction & $75.35 \pm 1.08$ & 0.00133 \\
\hline Boiling & $71.47 \pm 0.61$ & 0.00117 \\
\hline
\end{tabular}

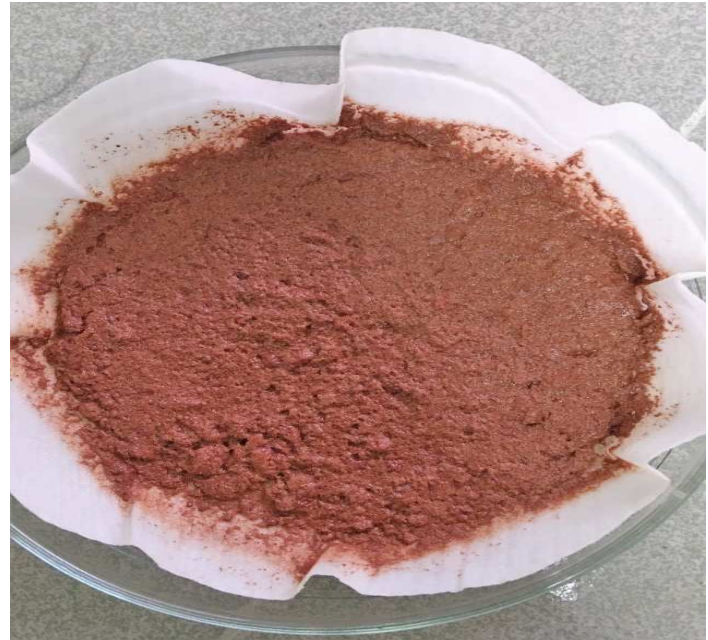

Fig. 9 Condensed tannin

\section{CONCLUSION}

The optimum parameters for the extraction of tannin were using water as the solvent while using alcoholic solvent does not increase the extractives percentages. Although the performance of extraction when using methanol and water is about the same, using water as solvent is much preferable to the industry, more environmentally friendly, cost-effective and possess less risk and side effects. A prolonged time of extraction and the usage of larger particle size reduced the effectiveness of the extraction. A large amount of sample can be used with boiling technique. However this reduced the selectivity of solvent, and the result was incomparable to conventional Soxhlet extraction. Therefore, conventional Soxhlet extraction is more effective for the extraction of tannin from the bark of Rhizophora Mucronata.

\section{ACKNOWLEDGMENT}

The authors extend our sincerest gratitude to the Ministry of Science Technology \& Innovation (MOSTI) for administering the provision to us in the form of research grants with the grant numbers of 600-IRMI/DANA 5/3/LESTARI (0028/2016), 600-RMI/FRGS 5/3 (0095/2016) 
and 600-RMI/FRGS 5/3 (98/2015). We would also like to thank the Research Management Institute (RMI) of Universiti Teknologi MARA (UiTM) for managing the funding for this research. We appreciate all the hard work and dedication provided by the staff and all those involved.

\section{REFERENCES}

[1] A. Guaadaoui, S. Benaicha, N. Elmajdoub, M. Bellaoui, and A. Hamal, "What is a bioactive compound? A combined definition for a preliminary consensus," International Journal of Nutrition and Food Sciences, vol. 3, no. 3, pp. 174-179, 2014.

[2] P. Wen, M.-H. Zong, R. J. Linhardt, K. Feng, and H. Wu, "Electrospinning: A novel nano-encapsulation approach for bioactive compounds," Trends in Food Science \& Technology, vol. 70, pp. 5668, 2017/12/01/ 2017

[3] N. Recharla, M. Riaz, S. Ko, and S. Park, "Novel technologies to enhance the solubility of food-derived bioactive compounds: A review," Journal of Functional Foods, vol. 39, pp. 63-73, 2017/12/01/ 2017.

[4] Y. Poodi, M. Bimakr, A. Ganjloo, and S. Zarringhalami, "Intensification of bioactive compounds extraction from Feijoa (Feijoa sellowiana Berg.) leaves using ultrasonic waves," Food and Bioproducts Processing, vol. 108, pp. 37-50, 2018/03/01/ 2018.

[5] S. Skrovankova, D. Sumczynski, J. Mlcek, T. Jurikova, and J. Sochor, "Bioactive compounds and antioxidant activity in different types of berries," International Journal of molecular sciences, vol. 16, no. 10, pp. 24673-24706, 2015.

[6] C. Hernández-Hernández, I. Viera-Alcaide, A. M. Morales-Sillero, J. Fernández-Bolaños, and G. Rodríguez-Gutiérrez, "Bioactive compounds in Mexican genotypes of cocoa cotyledon and husk," Food Chemistry, vol. 240, pp. 831-839, 2018/02/01/ 2018.

[7] E. Haslam, Chemistry of vegetable tannins. 1966.

[8] G. v. Poser and G. Gosmann, "Acácia-negra," Ciência Hoje, vol. 11, no. 63 , pp. $68-70,1990$.

[9] C.-Y. Yin, "Emerging usage of plant-based coagulants for water and wastewater treatment," Process Biochemistry, vol. 45, no. 9, pp. 1437-1444, 2010

[10] K. Frisch, L. Rumao, and A. Pizzi, Diisocyanates as wood adhesives (Wood Adhesives, Chemistry, and Technology. Ed. Pizzi, A.). New York: Marcel Dekker, Inc., 1983.

[11] P. Schofield, D. M. Mbugua, and A. N. Pell, "Analysis of condensed tannins: a review," Animal Feed Science and Technology, vol. 91, no. 1-2, pp. 21-40, 5/16/ 2001.

[12] S. Sulaiman, D. Ibrahim, J. Kassim, and L. Sheh-Hong, "Antimicrobial and antioxidant activities of condensed tannin from Rhizophora apiculata barks," Journal of Chemical and Pharmaceutical Research, vol. 3, no. 4, pp. 436-444, 2010.

[13] M. N. Clifford and A. Scalbert, "Ellagitannins-nature, occurrence and dietary burden," Journal of the Science of Food and Agriculture, vol. 80 , no. 7 , pp. $1118-1125,2000$

[14] M. On, L. H, O. Oo, and A. Ao, "Investigation of Tannin content in Diospyros mespiliformis Extract using Various Extraction Solvents," Journal of Analytical \& Pharmaceutical Research, vol. 7, no. 1, 2018.

[15] A. Pizzi, C. Simon, B. George, D. Perrin, and M. C. Triboulot, "Tannin antioxidant characteristics in leather versus leather light stability: Models," Journal of Applied Polymer Science, vol. 91, no. 2, pp. 1030-1040, 2004

[16] K. Joseph and N. Nithya, "Material flow in the life cycle of leather," Journal of Cleaner Production, vol. 17, no. 7, pp. 676-682, 2009/05/01/ 2009

[17] G. Krishnamoorthy, S. Sadulla, P. K. Sehgal, and A. B. Mandal, "Green chemistry approaches to leather tanning process for making chrome-free leather by unnatural amino acids," Journal of Hazardous Materials, vol. 215-216, pp. 173-182, 2012/05/15/ 2012.

[18] L. Rosu, C. D. Varganici, A. M. Crudu, D. Rosu, and A. Bele, "Ecofriendly wet-white leather vs. conventional tanned wet-blue leather. A photochemical approach," Journal of Cleaner Production, vol. 177, pp. 708-720, 2018/03/10/ 2018.

[19] R. Laurenti, M. Redwood, R. Puig, and B. Frostell, "Measuring the environmental footprint of leather processing technologies," Journal of Industrial Ecology, vol. 21, no. 5, pp. 1180-1187, 2017.
[20] K. Ramakrishnan and M. Krishnan, "Tannin-Classification, Analysis, and Applications," Ancient science of life, vol. 13, no. 3-4, p. 232, 1994.

[21] M. Rozainah and M. Mohamad, "Mangrove Forest Species Composition and Density in Balok River, Pahang, Malaysia," Ecoprint: An International Journal of Ecology, vol. 13, pp. 23-28, 2009.

[22] B. Satyanarayana, I. F. Idris, K. A. Mohamad, M.-L. Husain, N. A Shazili, and F. Dahdouh-Guebas, "Mangrove species distribution and abundance about local environmental settings: a case-study at Tumpat, Kelantan Delta, east coast of peninsular Malaysia," Botanica Marina, vol. 53, no. 1, pp. 79-88, 2010.

[23] A. A. Rahim, E. Rocca, J. Steinmetz, M. J. Kassim, R. Adnan, and M. Sani Ibrahim, "Mangrove tannins and their flavonoid monomers as alternative steel corrosion inhibitors in acidic medium," Corrosion Science, vol. 49, no. 2, pp. 402-417, 2// 2007.

[24] M. D. Luque de Castro and L. E. García-Ayuso, "Soxhlet extraction of solid materials: an outdated technique with a promising innovative future," Analytica Chimica Acta, vol. 369, no. 1-2, pp. 1-10, 1998.

[25] M. D. Luque de Castro and F. Priego-Capote, "Soxhlet extraction: Past and present panacea," Journal of Chromatography A, vol. 1217, no. 16 , pp. 2383-2389, 2010.

[26] J. Luque-Garcia and M. L. de Castro, "Where is microwave-based analytical equipment for solid sample pre-treatment going?," TrAC Trends in Analytical Chemistry, vol. 22, no. 2, pp. 90-98, 2003.

[27] E. Aspé and K. Fernández, "The effect of different extraction techniques on extraction yield, total phenolic, and anti-radical capacity of extracts from Pinus radiata Bark," Industrial Crops and Products, vol. 34, no. 1, pp. 838-844, 2011.

[28] C. Fotakis et al., "Metabolic and antioxidant profiles of herbal infusions and decoctions," Food Chemistry, vol. 211, pp. 963-971, $11 / 15 / 2016$.

[29] K. W. Tan and M. J. Kassim, "A correlation study on the phenolic profiles and corrosion inhibition properties of mangrove tannins (Rhizophora apiculata) as affected by extraction solvents," Corrosion Science, vol. 53, no. 2, pp. 569-574, 2// 2011.

[30] P. W. Hartzfeld, R. Forkner, M. D. Hunter, and A. E. Hagerman, "Determination of hydrolyzable tannins (gallotannins and ellagitannins) after reaction with potassium iodate," Journal of Agricultural and Food Chemistry, vol. 50, no. 7, pp. 1785-1790, 2002.

[31] H. Y. Baldosano, B. Castillo, C. D. H. Elloran, and F. T. Bacani, "Effect of Particle Size, Solvent and Extraction Time on Tannin Extract from Spondias purpurea Bark Through Soxhlet Extraction," in Proceedings of the DLSU Research Congress, 2015, vol. 3.

[32] A. Zalacain, M. Prodanov, M. Carmona, and G. L. Alonso, "Optimisation of Extraction and Identification of Gallotannins from Sumac Leaves," Biosystems Engineering, vol. 84, no. 2, pp. 211-216, 2003.

[33] M. C. Vieira, R. C. C. Lelis, B. C. da Silva, and G. de Lima Oliveira, "Tannin extraction from the bark of Pinus oocarpa var. oocarpa with sodium carbonate and sodium bisulfite," Floresta e Ambiente, vol. 18, no. 1 , pp. 1-8, 2011.

[34] H. Purushotham, A. Koshy, V. S. Rao, and P. Latha, "Computer based technology for vegetable tannin extraction," Journal of the Society of Leather Technologists and Chemists, vol. 78, no. 6, pp. 178-86, 1994.

[35] M. S. Gião, C. I. Pereira, S. C. Fonseca, M. E. Pintado, and F. X. Malcata, "Effect of particle size upon the extent of extraction of antioxidant power from the plants Agrimonia eupatoria, Salvia sp. and Satureja montana," Food Chemistry, vol. 117, no. 3, pp. 412-416, 2009.

[36] M. Naczk and F. Shahidi, "Extraction and analysis of phenolics in food," Journal of Chromatography A, vol. 1054, no. 1, pp. 95-111, 2004 .

[37] E. Silva, J. Souza, H. Rogez, J.-F. Rees, and Y. Larondelle, "Antioxidant activities and polyphenolic contents of fifteen selected plant species from the Amazonian region," Food Chemistry, vol. 101, no. 3, pp. 1012-1018, 2007.

[38] B. E. Richter, B. A. Jones, J. L. Ezzell, N. L. Porter, N. Avdalovic, and C. Pohl, "Accelerated Solvent Extraction: A Technique for Sample Preparation," Analytical Chemistry, vol. 68, no. 6, pp. 1033 1039, 1996/01/01 1996.

[39] I. Mueller-Harvey, "Analysis of hydrolysable tannins," Animal Feed Science and Technology, vol. 91, no. 1-2, pp. 3-20, 2001. 